\title{
A LIBERDADE IGUAL NO ESTADO CONSTITUCIONAL DE DIREITO SOB A PERSPECTIVA DO CONTRATUALISMO DE JOHN RAWLS
}

\author{
Leonam Baesso da Silva Liziero ${ }^{1}$
}

LIZIERO, L. B. da S. A liberdade igual no estado constitucional de direito sob a perspectiva do contratualismo de John Rawls. Rev. Ciênc. Juríd. Soc. UNIPAR. Umuarama. v. 17, n. 1, p. 53-82, jan./jun. 2014.

RESUMO: Este artigo pretende mostrar como o princípio da liberdade igual está presente na concepção contemporânea de Estado de Direito. A liberdade igual como concepção de justiça, desenvolvido no trabalho de Rawls, sob a ótica da contratualismo, tem um papel de referencial para o alcance de uma constituição justa. Em seguida, a investigação discute o papel da liberdade nas principais teorias do contratualismo clássico. Posteriormente, mostrará as influências kantianas sobre o pensamento de Rawls, principalmente a respeito da abordagem contratualista para obter uma concepção razoável de justiça, com base em um sistema de liberdades no Estado de Direito.

PALAVRAS-CHAVE: Liberdade Igual; Contratualismo; John Rawls.

\section{INTRODUÇÃO}

A liberdade é tratada ora como fundamento dos direitos fundamentais, ora como direito fundamental em si. Na construção gradativa do Estado Moderno, houve uma gradativa afirmação da liberdade como um direito frente à opressão do próprio poder público. Dentre muitas liberdades, a liberdade de expressão se destaca por permitir o diálogo na esfera pública e garantir o respeito a outras garantias fundamentais.

A questão sobre o que fundamenta os direitos fundamentais é inquietante e oscila frequentemente no pensamento jurídico. A fundamentação pode ser um exercício constante de regressão de ideias, sempre a procura do fundamento do fundamento, o que causa o problema epistemológico de se explicar, provocando muitas vezes um regresso ao infinito. Ao se afirmar que determinado direito é fundamental, há o problema de se encontrar o porquê dele ser tido como fundamental, ou seja, o que constitui a base de sua caracterização diversa dos demais direitos e a investigação do direito fundamental em espécie.

A liberdade componente do agir e da vontade humana, questiona-se se

DOI: https://doi.org/10.25110/rcjs.v17i1.2014.5355

'Doutorando e Mestre em Teoria e Filosofia do Direito pela Universidade do Estado do Rio de Janeiro

- UERJ. Professor da Universidade Candido Mendes. Advogado.

Rev. Ciênc. Juríd. Soc. UNIPAR, v. 17, n. 1, p. 53-82, jan./jun. 2014 
poderia ser entendida como fundamento e como o direito em si. Em outras palavras, ao se investigar a indagação "o que torna a liberdade um direito fundamental", há o problema de se explicar racionalmente a indagação "a liberdade é o fundamento dos direitos fundamentais ou um direito fundamental". O que torna a liberdade crucial para o sistema de direitos é ela é o pressuposto do próprio sistema? O que os direitos fundamentais fundamentam?

Fundamentar é procurar evidência para se constatar a validade de uma determinada concepção. A fundamentação dos direitos que por sua vez fundamentam (por serem fundamentais) é um dos grandes desafios da filosofia do direito e da política, sobretudo no que se refere à epistemologia de tais direitos, ou seja, como conhecer e conceber de forma científica e racional um direito fundamental. Neste caso, seria a liberdade que fundamenta os direitos fundamentais ou ela é fundamentada por esses direitos?

Inicialmente é preciso traçar um breve entendimento sobre o sentido da liberdade. Evidentemente seriam necessários tratados para esgotar o tema, mas neste contexto serão trabalhadas certas ideias de liberdade, principalmente, construídas durante o Estado Moderno e como o respeito à liberdade da pessoa é imprescindível para a efetivação de demais direitos ditos fundamentais.

Conforme a possibilidade de fundamentar os direitos, lecionado por Perelman (1996, p. 394), é necessário a investigação acerca do que torna fundamental um direito. Para tanto, "a busca de fundamentos suficientes, mas relativos a um espírito, a uma sociedade ou a uma disciplina determinadas, se torna filosoficamente essencial para todos". Ao ser invocada a liberdade em um sistema de direitos fundamentais, é preciso ter uma relativa resposta do porquê a liberdade permite a estruturação jurídica deste sistema.

Tal afirmação encontra respaldo na hipótese formulada na segunda metade do Século XX por John Rawls, que ao tentar construir uma sociedade justa encontra como o primeiro princípio de sua concepção de justiça, a liberdade. A liberdade formulada por Rawls tem um sentido diferente do que foi teorizada por Hobbes e outros pensadores contratualistas, todavia carrega o mesmo valor de importância para a justiça.

Procuraremos não estabelecer uma perspectiva histórica do direito de liberdade, mas sim um diálogo entre alguns filósofos que deram uma especial atenção a este direito ao construírem suas teorias jurídicas e políticas. Será utilizada a teoria da Justiça como Equidade de Rawls como o eixo da discussão inicialmente, de forma a sempre tentar corresponder esta teoria com as clássicas apontadas. 


\section{AS INSPIRAÇÕES DE RAWLS NO CONTRATUALISMO CLÁSSICO}

John Rawls dedica sua teoria a tentar formular como seria possível definir a justiça. Neste objetivo, atrela a ideia de justiça com a instituição social. O objeto da justiça seria a estrutura básica da sociedade. Entende-se por estrutura básica no pensamento de Rawls (2008, p. 102) "um sistema de normas públicas que define um esquema de atividades que conduz os homens a agirem juntos a fim de produzir um total maior de benefícios e atribui a cada um deles certos direitos reconhecidos a uma parte dos ganhos." A teoria da justiça como equidade busca então uma concepção de justiça que possa tornar justa esse sistema de normas públicas. Assim, para que seja possível definir a justiça, é necessário definir a sociedade justa.

Rawls revisita o contratualismo e o utiliza com grande grau de abstração para se definir a concepção de justiça. Como produto da racionalidade dos signatários que tem sua imparcialidade garantida pelo véu da ignorância, a concepção de justiça é formada por dois princípios que seriam imperativos de forma lexical. Ao estruturar a sociedade a partir desses dois princípios basilares, seria possível, para Rawls, a institucionalização da sociedade justa.

O primeiro destes dois princípios de justiça produtos da racionalidade imparcial dos signatários do pacto abstrato, acordo original, é o da liberdade igual. A norma contida neste imperativo é de que as pessoas devem ser livres e tal liberdade somente pode ser restringida para assegurar o exercício das demais liberdades. Este princípio é superior em ordem lexical ao segundo, que trata da igualdade de oportunidade de acesso aos cargos públicos e à redistribuição dos bens primários, entre os quais, a própria liberdade.

Será tratado aqui inicialmente do primeiro princípio. A liberdade que trata o primeiro princípio pode ser multifacetada, pois a liberdade pode ser percebida em inúmeros aspectos. Os exercícios dessas faces das liberdades muitas vezes entram em choque, situações o exercício de uma pode impedir o exercício da outra. Rawls apresenta-nos alguns destes conflitos e estabelece um critério de ponderação simples, ao estabelecer que somente para assegurar o exercício de um conjunto de liberdades, a liberdade individual de alguém pode ser tolhida.

A liberdade assim é entendida como o primeiro produto da racionalidade do sujeito na posição original, o "estado de natureza" de Rawls, uma vez que se deve pressupor que todo homem é naturalmente inclinado à liberdade. ${ }^{2}$ Esta racionalidade é debatida entre os pares, que priorizam o princípio da liberdade

\footnotetext{
2"A natural human inclination is to be free-free to think, to believe or disbelieve, and to pursue what constitutes his/her best interests. The individual is not true to his/her nature unless and until he enjoys the basic freedoms - notably, those of conscience, thought, association, and action." In: BALOGUN, J.M. Hegemony and Sovereign Equality: the Interest Contiguity in International Relations Springer. p.6
} 
igual como a regra mais basilar para estruturar a sociedade. A liberdade não é um direito em razão de uma força transcendental ou da própria natureza e sim a parte da concepção de justiça estruturante em uma sociedade formulada na posição original como resultado do contrato hipotético de Rawls.

A abordagem contratualista foi a que segundo Rawls poderia explicar o surgimento das concepções de justiça. O contratualismo é o método filosófico de abordagem em que se identifica uma hipótese metodológica anterior à instituição do Estado, comumente chamado de estado de natureza, em que devido à uma anormalidade com seus direitos naturais, os homens realizam um contrato e instituem um ente político. Billier (2005, p. 147) observa que "o contrato é um procedimento dialético no qual a totalidade das liberdades individuais naturais converge para o Estado, que vai redistribuí-las consagradas com o selo do direito positivo". O consenso razoável com implicações morais é uma característica comum em todas as teorias contratualistas, como aponta Scanlon (2003, p. 227), ainda que sejam diversas em seus pressupostos e em seus resultados.

O contratualismo rawlsiano se diferencia dos demais pela ausência de direitos, como a liberdade, inerentes no estado de natureza. A origem da liberdade em Hobbes se diferencia por estar presente em uma fase anterior ao pacto e não como resultado. Apresenta uma concepção selvagem da liberdade, que existe antes do pacto, mas que necessita da instituição para ser definida e exercida.

Como muitos outros direitos conferidos pela natureza, a liberdade é inerente ao homem por ser homem, para que este possa preservar sua própria vida. Todavia, a liberdade absoluta do estado de natureza é uma das causas que caracterizam esta situação também como um estado de guerra, pois nada pode assegurar a segurança do homem, que garantiria o exercício deste direito. ${ }^{3}$

No estado de natureza, todos os homens teriam a liberdade ilimitada, sendo impossível a convivência entre eles sem que houvesse a ameaça à segurança. A liberdade, neste sentido, seria a "ausência de impedimentos externos, impedimentos que muitas vezes tiram parte do poder que cada um tem de fazer o que quer, mas não pode obstar a que use o poder que lhe resta, conforme o seu julgamento e razão ditarem" (HOBBES, 1983, p. 78). Esta ideia de liberdade é intrinsecamente relacionada com a de direito subjetivo, ou seja, a liberdade que o homem tem em fazer algo ou deixar de fazer algo.

Interessante observar que o homem possui aqui a liberdade em razão de ser um homem. A liberdade é um direito de natureza, inerente ao ser humano. $\mathrm{O}$ pacto de submissão tem um papel de restringir a liberdade em favor da segurança. Temos o direito de liberdade restrito para que seja assegurada a vida do ser

\footnotetext{
3"Durante o tempo em que os homens vivem sem um poder comum capaz de os manter a todos em respeito, eles se encontram naquela condição a que se chama guerra". In: HOBBES, Thomas. Leviatã. Trad. de João Paulo Monteiro. São Paulo: Abril Cultural, 1983. (Os Pensadores). p. 75
}

Rev. Ciênc. Juríd. Soc. UNIPAR, v. 17, n. 1, p. 53-82, jan./jun. 2014 
humano. Na forma teorizada por Hobbes, o único com direito de liberdade total é o soberano, que se sub-roga nos direitos do homem no estado de natureza. A lei do soberano, neste raciocínio, não leva ao direito e sim tem a função de restringir a liberdade.

O soberano torna-se a única autoridade. Tal autoridade é única dentro da organização política instituída pelo pacto e tem o poder de definir os direitos de cada súdito. Estes direitos são reafirmações daqueles direitos que os homens teriam no estado de natureza, mas estariam ameaçados. Dessa forma, o Leviatã reconhece direitos individuais dos súditos, mas os delimita no propósito da garantia da segurança. Estes direitos subjetivos são direitos privados, uma vez que no sistema hobbesiano, o indivíduo não teria o direito de se rebelar contra o Estado, já que se isto fizesse, romperia o pacto e logo, cometeria injustiça. A única hipótese em que isso não ocorreria seria a desobediência de uma ordem para que o indivíduo atentasse contra sua própria vida, já que é puramente derivada da natureza humana.

Essa preservação da vida era a principal ideia de lei natural hobbesiana e nos leva à sua importante diferenciação de lei e direito. A lei natural seria uma regra geral da razão que proíbe o ser humano de usar todos os meios necessários para conservar sua vida, ou o obrigue a uma conduta com esse fim. A lei sempre proíbe ou obriga a uma conduta. Por sua vez o direito nada mais é que a liberdade de fazer ou não fazer. A liberdade é entendida como a ausência de óbices à conduta do indivíduo. A lei não concede a liberdade, mas sempre procura restringi-la de alguma forma e para algum propósito.

A lei do Estado-Leviatã limita a liberdade dos indivíduos. O Estado confere a liberdade ao indivíduo somente para assegurar a própria organização política, mas de forma que em comparação ao poder de exercício no estado de natureza, seria muito limitado. O Estado ao se sub-rogar nos direitos dos indivíduos, torna-se também o detentor da violência que eles poderiam usar no estado de natureza para assegurar seus direitos naturais. O soberano, no exercício dos seus direitos por instituição seria:

A base de toda a autoridade. Leis são leis em virtude de sua origem e de suas sanções, não em virtude de sua razão. A supremacia da autoridade do Estado espelha a liberdade natural do indivíduo; o Leviatã, parceiro perfeito e necessário limite do indivíduo, não apenas compartilha, mas também inaugura os atributos do indivíduo (DOUZINAS, 2009, p. 91).

Em Hobbes a liberdade do indivíduo seria a capacidade de exercer seus direitos naturais, mas condicionados pela vontade do soberano. A liberdade dentro do Direito do Estado neste raciocínio não tem como fonte a racionalidade 
daqueles signatários do pacto, mas sim é produto da vontade e da discricionariedade do soberano.

Esta concepção de liberdade se diferencia muito da elaborada por John Locke. No estado de natureza (que neste caso não é um estado de guerra) o homem é dotado de direitos naturais indisponíveis passíveis de serem conhecidos pela razão. Todavia, como o homem não consegue conviver com as leis naturais plenas, uma vez que por ignorância não estudam a lei natural para aplicá-la em casos particulares, acaba por gerar inconvenientes em relação ao direito natural de propriedade. Da mesma forma, apesar dos homens conseguirem viver em liberdade e tirarem os devidos frutos de seu trabalho, o estado de natureza é caracterizado pelos temores de invasões externas, daqueles que são pouco observadores da equidade. Devido aos temores de ameaça à fruição da propriedade, a sociedade civil elabora o contrato social que funda o Estado, cuja principal razão de existir é a proteção do direito de propriedade.

Propriedade e liberdade são intrinsecamente ligadas. O exercício de seu direito de propriedade do cidadão é um exercício de sua liberdade. A propriedade resultada do próprio trabalho se torna uma extensão do corpo do próprio cidadão ${ }^{4}$, fazendo parte de sua esfera privada individual, na qual ele pode ter o pleno exercício de seus direitos que a natureza o conferiu. O governo deve garantir a não interferência na esfera privada do cidadão, a não ser que esteja cumprindo sua função de proteção geral da propriedade da sociedade civil.

A liberdade consiste no direito do cidadão não ter sua esfera privada invadida por uma ação do Estado, pois o Direito do Estado serve apenas ao propósito de assegurar a propriedade do indivíduo. A lei do Estado neste contexto tem a finalidade de assegurar a liberdade e não puramente de torná-la restrita, liberdade esta cognoscível para o homem ainda no estado de natureza, que não desaparece com a instituição do governo. Neste raciocínio, observa Billier que "com Locke, parece se efetuar uma notável tomada de consciência da modernidade política por ela mesma: o direito, que comanda, prescreve, limita etc., em sua própria essência, tem também fundamentalmente por essência assegurar a liberdade." (BILLIER, 2005, p. 147).

É nítida a ideia de liberdade individual como legitimação do Estado. A sociedade civil institui o Estado para servi-la, para garantir sua liberdade e seus bens, direitos estes naturalmente concebidos. Temos aqui a separação de Estado da sociedade civil, um dos pontos mais importantes liberalismo político de John

\footnotetext{
${ }^{4 "}$ Cada homem tem uma propriedade em sua própria pessoa; a esta ninguém tem qualquer direito senão ele mesmo. O trabalho do seu corpo e a obra das suas mãos, pode dizer-se, são propriamente dele. Seja o que forma que ele retire do estado que a natureza lhe forneceu e no qual o deixou, fica-lhe misturado ao próprio trabalho, juntando-se lhe algo que lhe pertence, e, por isso mesmo, tornando-o propriedade dele." In: LOCKE, John. Segundo Tratado sobre o Governo. São Paulo: Abril Cultural, 1979, p. 45.
}

Rev. Ciênc. Juríd. Soc. UNIPAR, v. 17, n. 1, p. 53-82, jan./jun. 2014 
Locke.

O poder do Parlamento, ao representar a sociedade, permitiria que não houvesse ações do Estado além de sua principal diretriz, sendo a divisão do poder do Estado crucial para a garantia dos direitos do indivíduo. Se o Estado descumpre o contrato, ou seja, se passa a não garantir mais a manutenção do direito de propriedade individual, deixa de ser legítimo. A correspondência entre o direito natural da liberdade e da propriedade e o direito positivo do Estado é bem clara: o segundo encontra sua validade no primeiro, que existe acima das leis humanas.

As leis do Estado encontram seu "fundamento na norma de direito natural, que reside na instância suprema do julgamento, as instituições, longe de serem os obstáculos da liberdade dos homens, são os instrumentos e as garantias" (FARAGO, 2004, p. 168). O direito emitido pelo Estado somente será válido se não entrar em conflito com os direitos naturais do homem. Em oposição ao desenvolvido por Thomas Hobbes, para quem o direito natural existe somente no estado de natureza, John Locke concebe que o homem permanece como titular de direitos naturais e em nome deles pode se opor ao Estado.

O contratualismo tem uma abordagem diferente no Século XVIII, em Rousseau e em Kant. De forma semelhante a Locke, Rousseau concebe um contrato social como o método para explicar a ascensão do Estado. O ponto de partida também é semelhante: a concepção antropológica do ser no estado de natureza como bom e livre. Uma vez que o estado de natureza começa a oferecer riscos à existência do indivíduo, há a necessidade de se estabelecer o pacto para que os homens se unam para superar essas forças hostis do estado de natureza ${ }^{5}$. O pacto seria a junção da força e da liberdade do cada indivíduo, pois são os meios principais que cada um tem para sua própria conservação.

O contrato social cria obrigações recíprocas entre o público e particular. O indivíduo se obriga com os outros e com o Estado. Apesar de se considerar acorrentado no estado civil, o homem é capaz de obter novas vantagens. $\mathrm{O}$ sentido de liberdade é modificado com passagem do homem no estado de natureza para o estado civil. Enquanto no primeiro caso a liberdade é o sentido mundano, coloquial, em que o indivíduo pode fazer tudo aquilo que é fisicamente possível, no segundo caso, a liberdade é uma liberdade civil, limitada não pelas forças humanas, mas pela vontade geral, ou seja, as leis como expressão do poder soberano. Este último sentido de liberdade é a liberdade política, que o homem adquire somente com a constituição do pacto.

\footnotetext{
5"Suponhamos que os homens chegando àquele ponto em que os obstáculos prejudiciais à sua conservação no estado de natureza sobrepujam, pela sua resistência, as forças de que cada individuo dispõe para manter-se nesse estado. Então, esse estado primitivo já não pode subsistir, e o gênero humano, se não mudasse de modo de vida, pereceria”. In: ROUSSEAU, Jean-Jacques. Do Contrato Social. 2 ed. Trad. Lourdes Santos Machado. São Paulo: Abril Cultural, 1978, p. 31.
} 
No raciocínio de Rousseau, a lei é o que permite o ser humano ser livre ${ }^{6}$. O sentido de lei que é usado tem uma conotação estrita. Para Rousseau, somente pode se caracterizar como lei a expressão do poder soberano, baseada numa vontade geral popular. A lei é expressão do soberano e o soberano é a incorporação do povo, resultado do contrato social. Uma edição de uma norma emitida por um poder arbitrário não seria uma lei, pois não é a expressão da vontade geral e atentaria contra a liberdade política do indivíduo. A lei, no sentido semântico de Rousseau, evitaria o despotismo e a arbitrariedade daquele que governa o Estado. Somente em um Estado regido por leis podem oferecer a única liberdade que o homem pode ter na sociedade civil, a liberdade política. Esta concepção de liberdade política é extremamente importante para que se compreenda o fenômeno constitucionalista e a ideia de soberania popular presentes naquele tempo.

Verifica-se que a abordagem contratualista nas teorias políticas do século XVII e XVIII contribuiu para o desenvolvimento das contemporâneas concepções de soberania popular e garantias constitucionais como um reflexo da liberdade enquanto liberdade política. Entre os elementos que compõem o contemporâneo Estado de Direito, na lição de Jorge Reis Novais ${ }^{7}$, a ideia de liberdade política está presente em todos eles.

A concepção teórica dos direitos humanos surge também do contratualismo e se relaciona intimamente com a ideia metafísica da liberdade. Hobbes inaugura de forma primitiva o discurso de direitos subjetivo inerente ao homem. Ao partir da visão antropológica do mal selvagem, Hobbes formula sua hipótese de trabalho, o estado de natureza, como sendo uma situação em que o homem possui tudo e tem a liberdade de possuir tudo. Quem concebe isso ao homem? Sua própria razão e existência.

O direito natural é do indivíduo por ele ser indivíduo, não provindo por uma ordem transcendental ou cosmológica. A liberdade, como anteriormente dito, é inerente ao homem. Qual homem? Todos, pois todos os homens vivem no hipotético contrato de natureza hobbesiano, tendo direitos naturais inerentes ao seu ser e que podem usar de sua força e sua malevolência para exercer esses direitos e garantir sua sobrevivência. Apesar de não garantidos após o pacto de

\footnotetext{
"Só à lei se devem justiça e a liberdade. Só ela permitiu subjugar os indivíduos para torná-los livres, encadear-lhes a vontade com a sua própria autorização, fazer valer o seu consentimento contra sua recusa. [...] Para ele (Rousseau), a lei é o reflexo, neste mundo, de uma ordem transcendente". In: CHEVALliER, Jean-Jacques. As Grandes Obras Politicas de Maquiavel a nossos dias. São Paulo: Agir, 1989, p. 171.

7“O Estado social de Direito é indissociável da estruturação democrática do Estado, o que, se por um lado exclui, como veremos, a ideia de uma sua eventual antinomia ao Estado Democrático de Direito, rejeita igualmente, e desde logo, qualquer possibilidade de caracterização como Estados sociais de Direito de regimes onde não e verifique a existência de uma verdadeira democracia política." In: NOVAIS, Jorge Reis. Contributo para uma teoria do Estado de Direito: do Estado de Direito Liberal ao Estado Social e Democrático. Lisboa, Almedina, 2006.
}

Rev. Ciênc. Juríd. Soc. UNIPAR, v. 17, n. 1, p. 53-82, jan./jun. 2014 
submissão, a consequência de existência mútua dos direitos naturais inerentes ao homem levam à sua realização, sendo possível conceber seres humanos como sujeitos de direitos.

\section{LIBERDADE IGUAL E COMPLEXIBILIDADE DA LIBERDADE}

Seres humanos são detentores de liberdade. Essa é uma afirmação comum do contratualismo político ainda que com entendimentos diferentes sobre a liberdade. A liberdade, sonho metafísico desmistificado por Kant, é um desejo ao mesmo tempo de uma razão de ser do homem. Ao analisar em sua Crítica da Razão Pura se seria possível conhecer as ideias puras da razão pela metafísica tradicional, Deus pela liberdade e imortalidade, Kant conclui que é um esforço falho tentar obter o conhecimento a priori desses juízos. Como não é possível o conhecimento da coisa em si, somente dos fenômenos, pois o ato de conhecer é um fenômeno.

Apenas a liberdade, entre as três ideias puras da razão, pode ser provada na realidade, pelos efeitos que produz. Apesar de ser apenas uma abstração, a liberdade pode ser provada pelo agir, sendo então possível conhecê-la por meio da razão prática.

A liberdade não é o resultado da conduta, ela é a própria causa da ação. É um conceito e um fato. A liberdade não é possível ser conhecida pela razão pura, mas somente pelo agir e o agir nada mais é do que a liberdade; é o que torna o mundo prático possível. ${ }^{8} \mathrm{O}$ contrato, antes de tudo, procura regular a liberdade na instituição criada. Em Kant, a ideia de contrato toma forma diversa dos demais contratualistas, de forma que a liberdade, enquanto essência, não é limitada, recepcionada ou modificada pelo pacto.

Kant, de forma a refinar a doutrina do direito natural de tal forma a efetivamente o identificar com a ideia atual de direitos humanos, o estabelece como os critérios apriorísticos de justiça, resultando no equílibrio entre os arbítrios de todos os indivíduos. Assim, a liberdade de todos os indivíduos deve coexistir de forma que alguém não seja impedido de seguir o imperativo. ${ }^{9}$ A liberdade é tida

\footnotetext{
8“'A liberdade no sentido kantiano é então um ser estranho: é a única Ideia da razão que é também um fato de razão. A liberdade torna possível tanto o dever quanto o direito. Temos que admitir! Mas o que, por sua vez, torna possível a própria liberdade? Nada! Esta última questão aparentemente judiciosa é, todavia, em seu próprio fundo, esvaziada de sentido: a liberdade não poderia depender de condições, porque seria contraditório com sua natureza [...] Este é o sentido absoluto da liberdade: a liberdade é a atmosfera do mundo prático". In: BILLIER, Jean-Cassien; MARYIOLI, Aglaé. História da Filosofia do Direito. Trad. Maurício de Andrade. Barueri: Manole, 2005, p. 153.

${ }^{9} \mathrm{O}$ Imperativo, conforme o sentido dado por Kant, é a "representação de um princípio objetivo, enquanto obrigante para uma vontade, chama-se um mandamento (da razão), e a fórmula do mandamento chama-se Imperativo [...], os imperativos são apenas fórmulas para exprimir a relação entre leis objetivas do querer em geral e a imperfeição subjetiva deste ou daquele ser racional, da vontade
}

Rev. Ciênc. Juríd. Soc. UNIPAR, v. 17, n. 1, p. 53-82, jan./jun. 2014 
em dois aspectos: a liberdade como autonomia e como coexistência dos arbítrios. Como autonomia, o ser humano deve seguir o imperativo categórico no agir de tal forma como se àquela norma todos tivessem dado seu consentimento, sua vontade. Portanto, o imperativo é a forma pela qual a razão manifesta a vontade obrigada.

O contrato de Kant se difere dos demais anteriores por não ser uma mera ficção hipotética para a constituição e instauração do Estado perante a sociedade civil. O contrato kantiano não é um fato hipotético, mas sim uma ideia presente na qual um povo constitui um Estado pela convergência de suas vontades, formando uma vontade pública e geral ${ }^{10}$. O Estado para Kant não é uma coisa, mas uma pessoa moral, já que é o vórtice das vontades dos indivíduos que compõem determinada sociedade.

Neste sentido, entende-se sua preferência em À Paz Perpétua, descrita no primeiro artigo definitivo, por uma Constituição republicana, já que somente nessas Constituições é possível que o Estado cumpra seu papel de manter o arbítrio recíproco entre os cidadãos, ao mesmo tempo em que seria mais difícil um ato de guerra contra outro Estado, pois, dificilmente, a vontade convergente dos indivíduos em uma sociedade seria com isso concordante.

A Constituição republicana é ao documento jurídico que possibilita o agir heterônomo na proteção da liberdade, é uma concretização da vontade mútua dos indivíduos ${ }^{11}$. Kant trabalha com o republicanismo como uma oposição ao poder despótico do Estado, reconhecendo ser necessária a separação harmônica entre legislativo e executivo, de forma a se evitar o poder concentrado, ao contrário do despotismo, que é o poder autocrático daquele que emite o direito (KANT, 2011, p. 28). Neste sentido, o republicanismo é definido como antítese do despotismo.

O pacto kantiano é a identificação de uma máxima moral de forma a

humana”. In: KANT, Immanuel. Fundamentação da Metafísica dos Costumes. São Paulo: Abril Cultural, 1983, p. 123.

10“'Kant desenvolve então uma teoria contratualista, que se distingue das de seus antecessores por não pressupor que a liberdade seja limitada, mas sim deixada totalmente em favor da aquisição da liberdade como autonomia: o homem abandona a "liberdade selvagem e sem lei" para "reencontrar em um estado jurídico sua liberdade em geral.” In: NOUR, Soraya. À Paz Perpétua de Kant: Filosofia do Direito Internacional e das Relações Internacionais. São Paulo: Martins Fontes, 2004, p. 41.

${ }^{11}$ Kant entende ser a constituição republicana como aquela que corresponde ao contrato originário, ou seja, a coexistência dos arbítrios entre os indivíduos em uma sociedade, possibilitando o exercício das duas liberdades. Em suas palavras, "a Constituição instituída primeiramente segundo os princípios da liberdade dos membros de uma sociedade (como homens), em segundo lugar segundo todos os princípios de dependência de todos com uma única legislação comum (como súditos) e terceiro, segundo a lei da igualdade dos mesmos (como cidadãos) - a única que resulta da ideia de contrato originário, sobre a qual tem que estar fundada toda legislação jurídica de um povo - é a constituição republicana". KANT, Immanuel. À Paz Perpétua. Trad. Marco Zingano. Porto Alegre; L\&PM Pocket, 2011, p. 26.

Rev. Ciênc. Juríd. Soc. UNIPAR, v. 17, n. 1, p. 53-82, jan./jun. 2014 
tornar possível a coexistência de vontades emanadas pela razão humana e que deve ser seguida por essa mesma vontade, uma vez que o indivíduo deve agir pensando no agir de todos os outros. ${ }^{12} \mathrm{~A}$ ideia de moralidade, expressada pela razão na forma do imperativo, está associada à de liberdade. Ao agir conforme o imperativo categórico, o indivíduo é autônomo. A autonomia "envolve dois componentes. O primeiro é que nenhuma autoridade externa é necessária para constituir ou nos informar das regras de moralidade. [...] O segundo é que no autogoverno podemos efetivamente nos controlar" (SCHNEEWIND apud GUYER, 1992, p. 309 $)^{13}$ Sendo autônomo, é livre para seguir a finalidade de sua existência - a felicidade - em conformidade com o imperativo criado por sua razão em um exercício de vontade. A liberdade como autonomia é o primeiro aspecto de liberdade de Kant.

Consideramo-nos como livres na ordem das causas eficientes, para nos pensarmos submetidos a leis morais na ordem dos fins, e depois pensamo-nos como submetidos a estas leis porque nos atribuímos à liberdade da vontade; pois liberdade e própria legislação da vontade são ambas autônomas, portanto conceitos transmutáveis, um dos quais porém não pode, por isso mesmo, ser usado para explicar o outro e fornecer seu fundamento, mas quando muito apenas para reduzir a um conceito único, em sentido lógico, representações aparentemente diferentes do mesmo objeto (como se reduzem diferentes frações do mesmo valor às suas expressões mais simples) (KANT, 1983, p. 152).

O segundo aspecto de liberdade é a limitação do arbítrio de todos os indivíduos por todos os indivíduos. Kant então concilia a ideia de liberdade como o agir conforme as máximas morais com a limitação do agir em nome do respeito mútuo à liberdade dos demais. Todos os indivíduos são autônomos e essa autonomia se completa na sua própria limitação, que estabelece um contrato de vontade pelo agir, no qual cada está obrigado com os demais.

\footnotetext{
12“'Da pressuposição desta ideia decorreu porém também a consciência de uma lei de ação que diz que os princípios subjetivos das ações, isto é, as máximas, tem que ser sempre tomados de modo a valerem também objetivamente, quer dizer, a valerem universalmente como princípios e portanto a poderem servir para nossa própria legislação universal" In: KANT, Immanuel. Fundamentação da Metafísica dos Costumes. São Paulo: Abril Cultural, 1983, p. 151.

13“"Autonomy involves two components. The first is that no authority external to ourselves is needed to constitute or inform us of the demands of morality. We can each know without being told what we ought to do because moral requirements are requirements we impose on ourselves. The second is that in self-government we can effectively control ourselves. The obligations we impose upon ourselves override all other calls for action, and frequently run counter to our desires. In: SCHNEEWIND, J.B. Autonomy, obligation, and virtue: A overwiew of Kant,s moral philosophy. In: GUYER, Paul (org.) The Cambridge Companion of Kant. Cambridge: Cambridge University Press, 1992, p. 309
}

Rev. Ciênc. Juríd. Soc. UNIPAR, v. 17, n. 1, p. 53-82, jan./jun. 2014 
Esta obrigação com os demais instituída por este pacto, em que a assinatura é o agir conforme a lei moral se limita de forma que as liberdades sejam recíprocas e respeitadas se coaduna com a ideia de responsabilidade perante o outro ser humano, hoje tão em voga nos estudos dos direitos fundamentais. $\mathrm{O}$ imperativo categórico representa a vontade humana e é ao mesmo tempo seu fim. Para que e transforme em máxima universal, a vontade de todo ser humano precisa se transformar em uma vontade objetiva, somente sendo possível explicar a liberdade em um mundo inteligível, somente em um agir.

O sentido da liberdade como moralidade depende do cumprimento do imperativo categórico, a objetivação pelo agir da subjetividade volitiva. ${ }^{14}$ Deste modo, "a natureza racional existe como um fim em si. É assim que o homem se representa necessariamente a sua própria existência" (KANT, 1983, p. 135). Ao agir como ser livre e autônomo, o indivíduo deve considerar o ser humano como fim em si mesmo. Este é efetivamente o imperativo prático na qual todas as leis da vontade encontram sua fonte: "Age de maneira que uses a humanidade, tanto na tua pessoa como na de qualquer outro, sempre e simultaneamente como fim e nunca simplesmente como meio" (KANT, 1983, p. 135) Ao agir de forma a manter o equilíbrio entre os arbítrios, o indivíduo não está tendo sua liberdade limitada: a está reafirmando. ${ }^{15}$

A liberdade em Kant coexiste em duas faces, em duas concepções que se completam. Nesse sentido, explica Soraya Nour:

Com esses dois conceitos de liberdade, Kant estabelece uma vinculação entre princípios universais da razão prática e a natureza particular da vida das pessoas: o ser humano é considerado ao mesmo tempo ser racional que segue a lei moral (a qual todos poderiam dar seu consentimento), e ser que persegue seus interesses particulares (sua própria concepção de liberdade), sem impedir os outros de fazerem o mesmo (NOUR, 2004, p. 99).

\footnotetext{
14“"Manifestada pela lei mora (deves, logo podes), a liberdade está, de ora em diante, conformada em sua realidade; ela permanece tão incompreensível como antes; nem por isso penetramos mais a sua natureza, compreendemos, porém, a priori a sua possibilidade porque ela é condição da lei moral que nos é revelada no respeito e na obediência." In: CHÂTELET, François. História da Filosofia: Ideias, doutrinas. Vol 5. Trad. Guido de Almeida. Rio de Janeiro: Zahar Editores, 1974, pp. 30-31.

${ }^{15}$ "Kant is saying that the ends of others - if morally permissible - set limits to the ends we ourselves may pursue. We must respect the permissible ends of others, and we may make others serve our own purposes only when they as moral agents assent to such use, as when someone willingly takes a job working for another. Thus we may not pursue our own ends if they impermissibly conflict with the ends of others. We are also to forward the ends of others, a point to which I will shortly return." In: SCHNEEWIND, J.B. Autonomy, obligation, and virtue: A overwiew of Kant,s moral philosophy. In: GUYER, Paul (org.) The Cambridge Companion of Kant. Cambridge: Cambridge University Press, 1992, p. 322
} 
Em Rawls, com larga influencia do kantismo, a garantia de um sistema de liberdades é uma escolha racional desinteressada de cada um dos indivíduos. Conforme sua leitura sobre Kant, Rawls afirma que "uma pessoa age de modo autônomo quando os princípios de sua ação são escolhidos por ela como a expressão mais adequada possível de sua natureza de ser racional e livre" (RAWLS, 2008, p. 313). Independentemente da classe social ou das influencias de seu exterior, o ser humano poderia agir de acordo com a lei moral e isso o permitira ser livre, e uma vez que todos devem ser autônomos para serem livres, há uma pressuposição de igualdade como na possibilidade da autonomia.

Ao lado dessa busca pela garantia de liberdade, pode ser encontrada uma necessidade por igualdade. Apesar de muitas vezes serem tidas como antagônicas e até mesmo excludentes, liberdade e igualdade são ideias diferentes, mas que caminham juntas e se completam. Evidentemente a concepção de igualdade neste caso é a igualdade política, em que se observa que para que haja em uma instituição a liberdade política dos componentes, é necessário que pressuposta seja uma igualdade de condições entre eles.

A igualdade é uma ideia comum em todas as teorias da justiça. Apesar de não ser um princípio de justiça exatamente, a igualdade é um pressuposto lógico de aplicabilidade da justiça, pois em todas as teorias normativas de justiça há uma generalidade entre os seus destinatários. Mesmo que haja desigualdade entre grupos, ainda sim há igualdade decorrente da desigualdade. Ainda que em um sistema - que seria injusto na convicção de Rawls - certos grupos de homens recebessem mais privilégios institucionais e pudessem ter mais liberdades que outros por questões econômicas ou étnicas, ainda sim entre os menos favorecidos e menos livres haveria um padrão de igualdade na injustiça. Conforme explica Kelsen, "a regra de que os que são iguais devem ser tratados igualmente é uma conseqüência lógica do caráter geral de todas as normas de justiça" (KELSEN, 2011, p. 58). Portanto, ainda que em uma teoria que aos olhos de Rawls pudesse ser injusta, a igualdade estaria presente, ainda que para reafirmar uma desigualdade maior. A igualdade em uma teoria da justiça, como a de Rawls, é uma exigência da lógica (id. ibid, p. 61) não da própria justiça em si.

Desde Aristóteles, há a contemplação na ideia de igualdade, ainda que não de forma plena. Naquele momento, a igualdade era vinculada ao cidadão, figura totalmente desvinculada do homo sapiens como um todo. Apesar de afirmar que o homem é um animal político, nem todo homem poderia ser um animal político.

A igualdade alcança um refinamento maior a partir dos teóricos do Estado Moderno. A igualdade, em seu sentido formal, foi objeto de gradativos reconhecimentos, desde Hobbes. A universalidade da igualdade é um conceito que se tornou complexo com o aumento da própria complexidade das relações sociais. 
Nos pressupostos de um Estado de Direito, a igualdade deve estar presente em todas elas, como correlata da liberdade. Ao se afirmar que a lei deve ser geral e abstrata de forma a alcançar a todos, significa dizer em um primeiro momento que todos estariam sujeitos aos efeitos de determinada norma jurídica, sem distinção. Todos assim estariam iguais perante a lei e perante ela teriam sua liberdade. A liberdade de participação política é uma igualdade na participação política. Aquele que não é igual ao outro na sua expressão de vontade, não é tão livre quanto o outro, sendo menos autônomo politicamente. Este talvez seja o ponto tocado por Kant, com base no pensamento de Rousseau, sobre a lei ser a expressão da livre vontade popular. Ser livre é agir de acordo com as leis provindas de nossa vontade. ${ }^{16}$ Ao conceber que o homem é autônomo por seguir máximas provindas de sua racionalidade, concebe-se que todos os homens devem estar em uma situação e igualdade na formulação e participação desta máxima.

Como um herdeiro do pensamento de Kant, Rawls pensa em um sistema geral de liberdades em um âmbito interno, na instituição de uma sociedade justa com a justiça como equidade, e em um âmbito internacional, a ser desenvolvido em sua obra "O Direito dos Povos". Embora haja um aparente retrocesso nas questões universalistas dos direitos humanos ${ }^{17}$, as diversas facetas da liberdade são trabalhadas por Rawls na composição do sistema geral de liberdades. Tais liberdades fariam parte da principal composição dos direitos fundamentais dos cidadãos em um Estado.

Rawls inicia seu raciocínio de que a justiça seria a virtude primeira das instituições. Para tal, essa instituição deveria priorizar a inviolabilidade do indivíduo, mesmo em nome de um interesse geral. Esta primeira diretriz, que mais tarde comporá o em Rawls a concepção de justiça mais razoável, coloca freios à ideia de supremacia do interesse público sobre o particular. O interesse público deve existir, mas não de forma que justifique a violação de determinadas liberdades do indivíduo. Apenas quando tal liberdade comprometer de certa forma o sistema geral de liberdades é que poderia ser tolhida, mas somente de forma a preserva o sistema.

Rawls trabalha com alguns aspectos da liberdade de forma específica,

\footnotetext{
16“'O principal objetivo de Kant é aprofundar e justificar a ideia de Rousseau de que a liberdade consiste em agir de acordo com as leis que instituímos por nós mesmos. E isso não conduz a uma moralidade de obediência austera, mas sim a uma ética de auto-estima e respeito mútuo". In: RAWLS, John. Uma Teoria da Justiça. Trad. Jussara Simões. São Paulo: Martins Fontes, 2008, p. 313

${ }^{17}$ "No direito cosmopolita, Kant estabelece uma unidade entre as esferas interna e internacional. Sob esse aspecto, parece-nos que o pensamento de Rawls representa um certo retrocesso. Em $O$ direito dos povos, ele não apresenta a mesma posição original do direito interno esse dualismo tem relação com a questão dos direitos humanos". In: FERNANDES, Antonio de Pádua. A Fundamentação Ética do Direito Internacional em Kant: à Paz Perpétua. Revista Prisma Jurídico. vol. 3. São Paulo: Uninove, 2004 p.161-162
}

Rev. Ciênc. Juríd. Soc. UNIPAR, v. 17, n. 1, p. 53-82, jan./jun. 2014 
limitando-as em razão do que as partes em no acordo original considerariam para o desenvolvimento individual e para o exercício de sua personalidade moral. As liberdades fundamentais consagradas no primeiro princípio:

São especificadas por uma lista, que é a seguinte: a liberdade de pensamento e de consciência; as liberdades políticas e a liberdade de associação, assim como as liberdades especificadas pela liberdade e integridade da pessoa; e, finalmente, os direitos e liberdades abarcados pelo império da lei (RAWLS, 2000, p. 346).

Essas liberdades, consagradas no primeiro princípio de justiça, tem um caráter restrito, enumerando as liberdades primordiais, de forma a não generalizar e não comprometer o caráter prioritário da liberdade.

O pensamento por Rawls defendido sobre quais seriam as prioritárias liberdades provoca uma ruptura no pensamento liberal clássico ao não consagrar o direito de propriedade abrangente como uma liberdade primordial ou ainda como aquele direito o qual o Estado existe para proteger. Rawls defende a proteção da propriedade privada na medida em que ela é utilizada para o desenvolvimento das capacidades morais do homem ${ }^{18}$. Nesse sentido, uma concepção de propriedade absoluta contraria a concepção de justiça deliberada na posição original porque além de contrariar o segundo princípio não se enquadra nas liberdades protegidas pelo primeiro princípio.

A ideia de preservação das liberdades do cidadão na linguagem direito constitucional seria a garantia institucional de um núcleo rígido de direitos fundamentais. Esses direitos fundamentais não devem ser violados, nem em nome de um bem comum, ainda que esse bem comum cause benefício ao maior número de pessoas em uma sociedade. Este raciocínio é um ataque ao utilitarismo, corrente filosófica que se coaduna com ações do Estado com o fim de causar um bem-estar geral ao maior número de pessoas possíveis, ainda que haja a violação dos direitos (ou liberdades) de alguns.

\footnotetext{
18“"Entre as liberdades fundamentais da pessoa está o direito de adquirir e de ter o uso exclusivo da propriedade pessoal. O papel dessa liberdade é permitir uma base material suficiente para haver um sentimento de independência pessoal e auto-respeito, ambos essenciais para o desenvolvimento e exercício das capacidades morais. Duas concepções mais abrangentes do direito de propriedade, enquanto uma liberdade fundamental deve ser evitada. Uma dessas concepções amplia o direito de propriedade para que se incluam certos direitos de aquisição e herança, assim como o direito de possuir meios de produção e recursos naturais. $\mathrm{N}$ o tocante à outra concepção, o direito de propriedade inclui o direito igual de participar do controle dos meios de produção e recursos naturais, que devem considerar-se propriedade social. Essas concepções mais amplas não devem ser usadas porque não podem, a meu ver, ser consideradas necessárias para o desenvolvimento e exercício das capacidades morais." In: RAWLS, John. O Liberalismo Político. 2 ed. Trad. Dinah de Abreu Azevedo. São Paulo: Ática, 2000, p. 352.
} 
A liberdade em um sistema de garantia de direitos é um de seus fundamentos e também um dos próprios direitos subjetivos. No universo rawlsiano, a liberdade é um direito porque é o produto do equilíbrio reflexivo oriundo da racionalidade dos signatários hipotéticos em uma situação de imparcialidade e igualdade. A liberdade fundamenta a instituição social, sendo o primeiro princípio a ser seguido em uma concepção de justiça razoavelmente aceita em uma sociedade.

Como produto da escolha racional das partes, o princípio da liberdade igual surge como primeira diretriz de uma concepção razoável de justiça. Se a justiça se conceitua no equilíbrio entre os diversos interesses de partes em uma situação de igualdade, o que leva a este equilíbrio é a concepção de justiça formada pela conjugação entre os dois princípios e a regra de prioridade.

Como a liberdade é aquilo que permite as partes a chegarem ao equilíbrio e à concepção e justiça na posição original, este sistema não se sustentaria se a proteção à liberdade não fosse prioritária. ${ }^{19}$ Não meramente uma diretriz de justiça procedimental, este princípio se perfaz no agir racional das partes na posição original com a finalidade de garantir seus interesses ainda desconhecidos.

Após um refinamento de seu raciocínio, Rawls assim reformula o primeiro princípio da concepção de justiça como equidade: "Toda pessoa deve ter um direito igual ao sistema total mais abrangente de iguais liberdades fundamentais que seja compatível com um sistema similar de liberdade para todos". ${ }^{20}$

Ao buscar uma definição para liberdade, inicia por uma bruta definição no agir humano: os homens são livres, estão livres de alguma restrição e podem escolher o que fazer e o que não fazer. A liberdade em uma estrutura básica da sociedade se percebe então pelas disposições normativas a respeito da conduta humana, que define direitos e deveres..$^{21}$ Esses direitos baseiam-se em uma concepção de liberdade inviolável e que somente pode ser restrita quando o exercí-

\footnotetext{
19“'A posição original é especificada de forma a incorporar a devida reciprocidade e igualdade entre pessoas assim concebidas; e, já que seus objetivos e interesses fundamentais estão protegidos pelas liberdades de que trata o primeiro princípio, elas conferem prioridade a tal princípio". In: RAWLS, John. Uma Teoria da Justiça. Trad. Jussara Simões. São Paulo: Martins Fontes, 2008, p. 669

${ }^{20}$ RAWLS, John. Uma Teoria da Justiça. Trad. Jussara Simões. São Paulo: Martins Fontes, 2008, p. 311. Esta reformulação do primeiro princípio consta no final do Capítulo IV desta obra, após discutir os estágios que constituem a estrutura básica da sociedade, de conceituar a liberdade e de discutir alguns problemas que podem ser decorrentes deste conceito, Rawls reformula o primeiro princípio acoplando nele já a ideia de prioridade da ordem lexical. Somente pra verificar a diferença, o primeiro princípio em sua concepção bruta é "cada pessoa deve ter um direito igual ao sistema mais extenso de iguais liberdades fundamentais que seja compatível com um sistema similar de liberdades para as outras pessoas" (p.73).

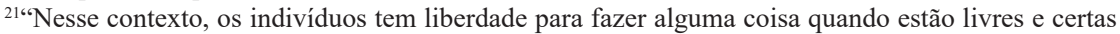
restrições, quer para fazê-la, quer para não fazê-la, e quando o ato de fazê-la ou não fazê-la está protegido contra a interferência de outras pessoas" In: RAWLS, John. Uma Teoria da Justiça. Trad. Jussara Simões. São Paulo: Martins Fontes, 2008, p. 248.
}

Rev. Ciênc. Juríd. Soc. UNIPAR, v. 17, n. 1, p. 53-82, jan./jun. 2014 
cio deste direito interfere e ameaça o sistema geral estabelecido. O destinatário de direitos e deveres não são apenas os particulares, mas também os funcionários do Estado, que não devem intervir em direitos do cidadão. Como o sistema de liberdades é um conjunto unificado, cada uma das liberdades depende da outra, sendo necessário em determinados casos estabelecer regulamentação para equilibrar liberdades quando em situação conflitante.

Esse é o objetivo do estabelecimento de uma concepção de justiça, tendo como ponto de partida "a estrutura das instituições básicas e os princípios, critérios e preceitos que se aplicam a ela, bem como a forma pela qual essas normas devem estar expressas no caráter e nas atitudes dos membros da sociedade que realizam seus ideais" (RAWLS, 2000, p. 54). Como o objeto da justiça é a estrutura básica da sociedade, ou seja, como as instituições sociais estabelecem a distribuição e direitos e deveres fundamentais e em decorrência disso, a divisão das vantagens provindas da cooperação entre as pessoas.

Rawls entende que as principais instituições são a constituição política e os arranjos socioeconomicos, que definem os direitos do cidadão daquela determinada sociedade de forma a repercutir em seus individuais projetos de vida. Nesse raciocínio, ao se definir a concepção de justiça na posição original, o passo seguinte para se estabelecer o sistema de normas públicas justas é a formulação da Constituição.

Sem entrar na discussão sobre o sentido político, sociológico ou jurídico, é utilizado o termo Constituição em seu sentido mais usual como a lei fundamental de um ordenamento, "que contém normas respeitantes à organização básica do Estado, ao reconhecimento e à garantia dos direitos fundamentais do ser humano e do cidadão, às formas, aos limites e às competências do exercício do Poder Público" (FERRAZ JUNIOR, 2007, p. 229). A Constituição nesses termos é o primeiro estágio para o estabelecimento da estrutura básica que concretiza a concepção de justiça.

Ao vincular a justiça com a estrutura básica da sociedade, Rawls concebe uma preocupação central com a justiça política, uma vez que o objeto da justiça é a constituição e as instituições sociais, a concepção de justiça a ser concretizada é uma concepção de justiça política, pois somente se encontra a justiça frente às instituições sociais.

As partes após o acordo original realizam a convenção constituinte. Não apenas a Constituição deve ser justa, mas também o procedimento para a escolha desta Constituição deve atender à concepção de justiça resultante do acordo original.

Rawls se depara com um problema no estabelecimento da Constituição após o acordo original: conceber uma Constituição justa de forma a se aproximar o máximo possível de uma justiça procedimental perfeita, ainda que essa não seja 
alcançável fatidicamente. A Constituição justa é uma concretização da justiça procedimental imperfeita, pois seria impossível alcançar a justiça procedimental perfeita.

Enquanto o procedimento são as etapas processuais que regem a Constituição, o resultado se definiria nas leis promulgadas, sempre com a limitação da concepção de justiça. Outro problema é a escolha, entre os arranjos procedimentais que sejam justos e factíveis, aquele que possivelmente possa estabelecer uma ordem jurídica justa e eficaz. A Constituição não deve ser apenas justa e aplicável, mas oferecer um sistema de estabilidade do direito a partir dela formada.

Como produto de uma justiça procedimental imperfeita, a Constituição, para Rawls,

deve ser um procedimento justo que satisfaça as exigências da liberdade igual; e, em segundo lugar, deve ser estruturada de modo que, dentre todos os arranjos justos viáveis, seja aquele que tem maiores probabilidades de resultar num sistema de legislação justo e efetivo (RAWLS, 2008, p. 273).

As partes "sujeitas às restrições dos princípios de justiça já escolhidos, devem elaborar um sistema para os poderes constitucionais do governo e para os direitos fundamentais dos cidadãos" (id. ibid, p. 241). A justiça no procedimental deve atender também ao princípio da liberdade igual no tocante à igualdade de liberdade na participação na convenção constituinte, ou seja, da lei fundamental do sistema de normas públicas que regeriam a sociedade. Sendo pressuposta na convenção constituinte, "a igualdade quer-se inicial e de circunstâncias, de forma a garantir uma representação equitativa dos cidadãos perante o poder político, representação essa definida na lei fundamental" (MELO, 2001, p. 7).

O princípio da liberdade igual ao ser aplicado ao procedimento político definido pela Constituição, define o princípio da igual participação política, que "exige que todos os cidadãos tenham um direito igual de participar do processo constituinte que define as leis às quais obedecer, bem como seu resultado final"( RAWLS, 2008, p. 273). O regime político escolhido pressuposto por Rawls para atender a concepção de justiça é o democrático.

O regime democrático que atenderia ao princípio da liberdade igual seria aquele em que o voto de cada um dos indivíduos, no exercício de sua liberdade política em escolher seus representantes no exercício do poder, pudesse ter o mesmo peso em comparação aos outros. Cada qual contaria com o mesmo peso, o voto de cada um teria o mesmo valor matemático no cômputo do resultado, de forma a assegurar a igualdade de condições entre os cidadãos. Uma possível desigualdade poderia ser justificada no caso de compensação com uma maior proteção das outras liberdades, como no caso das restrições ao alcance da regra 
da maioria na tomada das decisões. ${ }^{22}$ Não havendo tais restrições, Rawls acabaria por cair em uma deliberação de cunho utilitarista, o que violaria o caráter de ontológico de sua teoria.

O direito na teoria da justiça como equidade seria emitido com um fim de se aproximar de forma mais próxima possível da justiça e da eficácia. Legitimada por ter sido escolhida em um processo deliberativo e representativo, a Constituição tem a função primordial e garantir a estabilidade do sistema de liberdades mútuas. Efetivamente, justiça política e democracia caminham juntas para proporcionar a liberdade, realizando um ciclo interdependente de liberdade na participação política e outras liberdades pessoais. A justiça política se realizaria apenas com o regime democrático. ${ }^{23}$

Esse direito resultante da teoria rawlsiana é uma concepção de normas jurídicas justas e eficazes, ou melhor, mais justas e eficazes possíveis. O estabelecimento de normas jurídicas se coaduna perfeitamente com a problemática da liberdade desenvolvida por Rawls e pelos outros contratualistas. O direito estabelecido será composto de mandamentos que interferem em um daqueles ditames básicos de liberdade: ou uma permissão, uma proibição ou uma escolha dentro de um sistema de liberdades básicas. O direito rawlsiano é composto por normas jurídicas resultantes de um procedimento justo. As normas jurídicas ${ }^{24}$ compõem

\footnotetext{
22“"A extensão do princípio da participação é definida como a medida em que o procedimento da regra (pura) da maioria é limitado pelos mecanismos próprios do constitucionalismo.Esses instrumentos servem para limitar o alcance da regra da maioria, os tipos de questões em que a maioria não tem autoridade suprema e a rapidez com que os objetivos da maioria são postos em prática [...] Acredita-se que uma constituição que restringe a regra da maioria, por meio de vários expedientes tradicionais, conduz a um corpo de legislação mais justo". In: RAWLS, John. Uma Teoria da Justiça. Trad. Jussara Simões. São Paulo: Martins Fontes, 2008, p. 283.

${ }^{23} \mathrm{O}$ vínculo de democracia com liberdade demonstrada em Rawls foi de grande influência para Amartya Sen elaborar sua teoria, ao estender o conceito de liberdade com o de desenvolvimento humano. Em seu livro, Sen demonstra com dados empíricos que as pessoas conseguem maior desenvolvimento pessoal, ou seja, atenderem ao seu esperado e buscado preceito de liberdade, em Estados com o regime democrático. Em suas palavras, "os direitos políticos e civis dão às pessoas a oportunidade de chamar a atenção eficazmente para as necessidades gerais e exigir a ação pública apropriada. A resposta do governo ao sofrimento intenso do povo frequentemente depende da pressão exercida sobre esse governo, e é nisso que o exercício dos direitos políticos (votar, criticar, protestar etc.) pode realmente fazer a diferença. Essa é uma parte do papel instrumental da democracia e das liberdades políticas". In: SEN, Amartya. O Desenvolvimento como Liberdade. Trad. Laura Teixeira Mota. São Paulo: Companhia das Letras, 2010, p. 199.

${ }^{24} \mathrm{Se}$ coaduna com o sentido proposto por Rawls a lição de Goffredo Telles Junior: "São normas jurídicas, os mandamentos humanos, que, em sociedade, podem ser oficialmente exigidos e oficialmente proibidos. As normas sobre os outros movimentos humanos não são normas jurídicas. São normas de qualquer outra espécie. Jurídicas, somente são aquelas relativas a movimentos oficialmente exigíveis e oficialmente proibidos. Isto significa que somente são jurídicas, as normas relativas às interações que a inteligência governante considerada como necessárias, entre os homens de uma sociedade" In: TELLES JUNIOR, Goffredo. O Direito Quântico. São Paulo: Max Limonad, 1985, p. 288.
}

Rev. Ciênc. Juríd. Soc. UNIPAR, v. 17, n. 1, p. 53-82, jan./jun. 2014 
um ordenamento jurídico que estrutura a sociedade, coordenadas por uma espinha dorsal: a Constituição e as autoridades competentes dela decorrentes.

O direito e a liberdade são coexistentes no que Rawls poderia chamar de Estado de Direito. O Estado formulado à luz da concepção de justiça da posição original é o que tem em sua Constituição a segurança necessária ao cidadão para o exercício de sua liberdade. A Constituição atenderá aos preceitos de justiça se irradiar normas de tal forma que a interferência na liberdade do indivíduo seja somente quando o exercício e sua liberdade interferir na liberdade dos demais.

Os movimentos oficialmente exigíveis e proibidos são os que interferem de certa maneira na liberdade do destinatário da norma. Dentre as espécies normativas diversas, a lei expressa a vontade do legislador em atingir uma generalidade de pessoas com o fim de exigir ou proibir determinado comportamento. Esta vontade, por sua vez, deve estar de acordo com os mandamentos constitucionais, que regulamentam inclusive a liberdade do legislador. Na justiça como equidade, essa limitação se expressaria pela concepção de justiça, principalmente na garantia de um sistema de liberdades.

A liberdade de consciência, entre todas as faces da liberdade em Rawls, um das primordiais. Apesar do véu da ignorância retirar dos signatários o conhecimento sobre situações específicas e sua posição na sociedade, eles já podem reconhecer anteriormente este princípio. A liberdade de consciência, de forma a ser compatível com um sistema geral de liberdades, deve estar presente na Constituição do Estado. Portanto, o direito precisa assegurar a livre expressão da consciência de seus cidadãos, como forma atender ao princípio da liberdade igual. Na convenção constituinte desta sociedade justa, haveria a opção por um regime político no qual os direitos à livre escolha de práticas religiosas, de acepções morais e principalmente, a liberdade de pensamento, fossem respeitados e assegurados.

Essa liberdade de consciência deve ser somente regulada em casos da ameaça à liberdade de uma forma geral, no qual o Estado desempenha um papel de manutenção da ordem. ${ }^{25} \mathrm{~A}$ justificativa para Rawls não é a de que haja um interesse público acima das concepções morais de cada um, mas apenas o dever do Estado agir em conformidade com o que as partes no acordo original pactuaram a respeito da manutenção do sistema geral de liberdades. Um Estado livre de uma religião oficial é o que Rawls considera essencial para efetivamente ser possível a liberdade de consciência, pois é legítimo o Estado apenas para assegurar que os

\footnotetext{
25"Parece evidente que, ao limitar a liberdade de acordo com o interesse comum na ordem e na segurança públicas, o Estado age com base em um princípio que seria escolhido na posição original, pois, nessa posição, todos reconhecem que o comprometimento dessas condições representa um risco para a liberdade de todos." In: RAWLS, John. Uma Teoria da Justiça. Trad. Jussara Simões. São Paulo: Martins Fontes, 2008, p. 262.
} 
cidadãos tenham de forma igual o direito a se expressar. ${ }^{26}$

\section{ESTADO CONSTITUCIONAL DE DIREITO E LIBERDADE IGUAL}

A construção teórica do Estado de Direito na concepção delineada que é apresentada hoje se baseia em muitos aspectos na ideia de liberdade. Liberdade e Estado de Direito são correlatos. Muito mais que um mero "princípio" jurídico, o problema da liberdade é a todo momento tutelada pelo direito. A norma jurídica tem a primordial função e regular a conduta humana, resvalando em sua liberdade em qualquer de suas derivações.

O crescente espaço que o direito toma na vida social reflete na liberdade individual, tornando ainda mais complexa a acepção de liberdade: quanto maior for o número de normas de um ordenamento jurídico, regulando a conduta de uma sociedade, menos livres aparentemente seriam suas ações, que encontrariam um maior número de "fazer" ou "deixar de fazer". Em outra vertente, este mesmo inchaço normativo demonstra uma maior liberdade das ações, pois as normas são expressão da vontade geral, das mútuas liberdades, da autonomia.

Os direitos humanos são fundamentos morais que norteiam configuração da sociedade internacional após a Segunda Guerra Mundial. Apesar da ausência de força cogente da Declaração de 1948, as proposições ali enumeradas servem como diretrizes para as relações jurídicas de uma nova ordem mundial. Essa orientação, em se reconhecer normativamente tais direitos, é observada pelas várias Constituições promulgadas a partir do pós-guerra pelos Estados-membros das Nações Unidas ${ }^{27}$ e pelos tratados internacionais que versam sobre a matéria, o que constitui um regime sistêmico de proteção aos direitos humanos.

Neste cenário, emerge o constitucionalismo contemporâneo que revisita a teoria jurídica como um todo, rompendo antigos paradigmas e firmando bases de novas concepções na Teoria do Estado e do Direito e na Filosofia Política. O constitucionalismo alcança um papel central na ciência do Direito com as reconfigurações das funções do Estado, servindo como referencial paradigmático para as normas de outra natureza nas ordens jurídicas. Nesse sentido, afirma Antonio

\footnotetext{
26“'O Estado não pode favorecer nenhuma religião específica e nenhuma penalidade ou incapacidade legal pode estar vinculada a uma dada afiliação religiosa ou ausência dela. Rejeita-se a ideia de um Estado confessional. [...] Seu dever limita-se a garantir as condições de igual liberdade moral e religiosa". RAWLS, John. Uma Teoria da Justiça. Trad. Jussara Simões. São Paulo: Martins Fontes, 2008, pp. 260-262.

27“"As diversas concepções teorias acerca do modo pelo qual é possível alcançar esse desiderato, os limites do papel do direito e do Estado, têm o ponto de saída na Constituição que, independentemente do grau de recepção do Estado Nacional, possui um sentido forjado na tradição (revolução copernicana) exsurgente a partir do segundo pós-guerra”. In: STRECK, Lenio Luiz. Verdade e Consenso. 3ed. Rio de Janeiro: Lumen Juris, 2009, p. 34-35.
} 
Maia:

No domínio da filosofia política, a discussão acerca desse terceiro sentido se dá no debate relativo às formas de legitimação das estruturas jurídicas contemporâneas; encontra-se aqui, também, uma das novidades do cenário teórico contemporâneo - ensejadora de um quadro favorável à emergência de um novo paradigma jurídico: o crescente diálogo entre filosofia política e teoria constitucional, tendo como autores de referência Jürgen Habermas e John Rawls (MAIA, 2009, p. $50)$.

O sistema de garantias emergido deste fenômeno do Constitucionalismo constitui um núcleo rígido de uma Constituição em um Estado de Direito. A historicidade dessa concepção mostra que além de um governo de leis, e de limites ao poder soberano do Estado e para tal a divisão dos poderes, o Estado de Direito na contemporaneidade somente pode ser realizado com a proteção aos direitos fundamentais dos indivíduos.

Essa posição é defendida Jorge Reis Novais, para quem os direitos fundamentais não são apenas mais um elemento do Estado de Direito, mas sua finalidade. Conforme o professor português:

É a protecção dos direitos fundamentais que justifica o objectivo de limitação do Estado, pelo que a certeza e a segurança jurídica e as técnicas formais que lhe vêm associadas só cobram verdadeiro sentido e são susceptíveis de ser consideradas como valores a se desde que integradas, vinculadas e subordinadas à realização da axiologia material implicada na dignidade da pessoa humana (NOVAIS, 2006, p. 213).

O Estado Contemporâneo tem sua razão de ser para a proteção dos direitos do cidadão, em uma perspectiva muito mais ampla que o teorizado por John Locke. A emergência das necessidades básicas individuais direciona a proteção dos direitos de cunho social, apesar da dicotomia entre esses e os direitos puramente individuais ser equivocada. A realidade do Século XX demonstra não ser possível conceber separadamente os direitos de liberdade e direitos de igualdade como se fossem direitos antagônicos, quando na verdade suas funções teleológicas muitas vezes possam ser coincidentes.

Essa nova reinterpretação dos direitos se guia por uma tendência, no pensamento de Jorge Reis Novais, à socialidade, "que reflete uma dependência e vinculação social de seu exercício ou mesmo numa compreensão de seu conteúdo, determinadas pela necessidade de garantir condições de liberdade de todos os homens" (id. ibid., p. 201). 
O liberalismo igualitário contribui para uma nova visão de um Estado Constitucional de Direito, dentro do sistema de direitos humanos internacionalmente reconhecidos, como um dos paradigmas mínimos a serem observados pela autonomia dos Estados componente da sociedade internacional. Os direitos humanos na visão de Rawls alcançam uma amplitude diversa da proteção aos direitos fundamentais, servindo como condição de legitimação de regimes políticos a serem aceitos na sociedade internacional e para possibilitar um sistema que preserve a equalização entre os valores plurais dos diversos povos.

Os direitos humanos para Rawls se diferenciam dos direitos fundamentais garantidos pela Constituição por estabelecerem um critério mínimo a serem seguidos pelas instituições políticas internas, limitando minimamente a concepção de direitos fundamentais adotados por um Estado (RAWLS, 1999, p. 80). Neste raciocínio, "Rawls procura, em outras palavras, estabelecer uma norma comum, um direito cosmopolita, que servirá como critério universal para o reconhecimento dos sistemas políticos e jurídicos nacionais" (BARRETO, 2013, p. 247).

Em Rawls, os direitos humanos reconhecidos pela sociedade internacional, cumprem três papeis relevantes: inicialmente, a legitimação de um regime político ou de uma ordem jurídica, pois a observância dos direitos humanos no direito interno é uma condição para ser legítima e reconhecida internacionalmente como um Estado ou qualquer outro tipo de ente político. Em segundo lugar, a previsão e o consequente respeito aos direitos humanos pelos Estados reforçam sua soberania (em uma concepção contemporânea, diferente da ideia de poder absoluto), evitando a intervenção em seus assuntos por outros Estados ou organizações internacionais, como as sanções militares e econômicas. Por último, os direitos humanos estabelecem um limite ao pluralismo entre os povos, de forma a evitar um ressurgimento de uma ideia ilimitada de soberania externa e interna do Estado (RAWLS, 1999, p. 80).

Neste sentido, a proteção constitucional a esses valores morais nomeados direitos humanos, na forma de direitos fundamentais, corresponde à verdadeira proteção ao ser humano. Diferentemente dos direitos humanos da comunidade internacional, os direitos fundamentais tem um caráter realmente instrumental na concretização da concepção de justiça resultante da posição original.

De acordo com o que foi visto pelo pensamento de Rawls, uma Constituição que corresponda a uma concepção razoável de justiça deve ser normativa no sentido do Estado ser estruturado dentro do possível, em uma justiça procedimental imperfeita, de acordo com princípios de justiça na posição original convencionados. Se a estrutura básica da sociedade é o objeto da justiça, então a liberdade igual serve como referencial para se constituir um Estado de Direito. Nesse sentido, dentro de um núcleo rígido de direitos, aqueles tendentes à 
proteção das liberdades do indivíduo ocupam uma posição mais privilegiada na organização do Estado.

O debate a respeito da função da Constituição no Estado como garantia dos direitos é fomentado pelas concepções substancialistas e procedimentalistas. A concepção substancialista de uma Constituição consiste na obrigação do Estado em não apenas se abster de violar liberdades individuais, mas também de promover condições que os permitam o exercício de seus direitos básicos. A previsão constitucional de direitos vinculam o Estado em uma obrigação positiva de dar ou de fazer com seus cidadãos, não se prendendo somente à distribuição de bens primários, mas também da criação de condições de exercícios de forma a proteção do indivíduo. Nesse sentido, o Estado encontra uma finalidade de não apenas manter a paz interna, não violar direitos dos indivíduos e garantir a participação política no controle do poder, mas também em promover o desenvolvimento do ser humano em suprir suas necessidades básicas. A Constituição normativa é também um projeto de desenvolvimento do Estado, com obrigações de promover a concretização de direitos previstos, ainda que pela força da jurisdição constitucional.

Ao defender a tese materialista da constituição, na qual a implementação de direitos fundamentais é um fator que a legitima, Lenio Streck (2009, p. 25) leciona que:

As teorias materiais da Constituição reforçam a Constituição como norma (força normativa), ao evidenciarem o seu conteúdo compromissório a partir da concepção dos direitos fundamentais sociais a serem concretizados, o que, a toda evidência - e não há como escapar dessa discussão - traz à baila a questão da legitimidade do poder judiciário (ou da justiça constitucional para, no limite, isto é, na inércia injustificável dos demais poderes, implementar essa missão.

A intervenção do poder judiciário na proteção dos direitos do cidadão não afronta a garantia democrática do Estado de Direito quando sua atuação vai ao encontro da finalidade do Estado, que é justamente a promoção do núcleo rígido de direitos. Esse raciocínio leva a pensar que a liberdade do cidadão não pode ser limitada nem mesmo pela democracia que legitima o Estado. A liberdade continua a ser garantia na medida em que não é limitada por uma vontade da maioria. Isso possibilita a manutenção da liberdade de consciência e expressão de indivíduos, estejam entre a maioria ou não.

A liberdade em um Estado de Direito contemporâneo encontra respaldo nas prestações positivas do pode público, já que a própria construção da ideia de liberdade se modifica com a historicidade do Estado de Direito, apesar de não perder sua essência. A liberdade pode até não ser mais adstrita apenas sendo 
o exercício da propriedade privada como no contratualismo clássico lockeano, mas não deixa de se associar com a liberdade de consciência e sua decorrência, a liberdade de expressão. Além disso, a liberdade política não pode deixar de ser integrada ao conceito semântico de liberdade em um Estado de Direito, já que a limitação dessas liberdades afeta o regime democrático e não permite o desenvolvimento humano, podendo gerar inclusive grandes desastres humanos, conforme lecionado por Amartya Sen:

Houve fomes coletivas em reinos antigos e sociedades autoritárias contemporâneas, em comunidades tribais e em modernas ditaduras tecnocráticas, em economias coloniais governadas por imperialistas do norte e em países recém-independentes do sul, governados por líderes nacionais despóticos ou intolerantes partidos únicos. Mas nunca uma fome coletiva se materializou em um país que fosse independente, que tivessem eleições regularmente, partidos de oposição para expressar críticas e que permitisse aos jornais noticiar livremente e questionar a sabedoria das políticas governamentais sem ampla censura (SEN, 2010, p. 201).

Mesmo Rawls entendendo ser a Constituição um produto de justiça procedimental resultante de um procedimento que deve ser o mais próximo possível da concepção da justiça como equidade ${ }^{28}$, ainda reconhece que esse procedimento democrático e representativo sofre restrições em relação a direitos que não podem ser atingidos pelo princípio da maioria. Isso significa que pela lógica constitucional, ainda que fosse produto da emanação da vontade popular, uma norma que afetasse a liberdade de um grupo minoritário, não corresponderia à concepção razoável de justiça.

Ainda que o sistema teorizado por Rawls fosse possível apenas em uma sociedade democrática, pois de outra forma não haveria a participação do cidadão na formulação do poder político, esta democracia não é total, uma vez que ela não pode servir de instrumento para limitar direitos instituídos na Constituição. Em razão disso, a função da Constituição em Estado de Direito para Rawls não é meramente garantir o procedimento democrático, mas também estabelecer uma forma de proteção das liberdades fundamentais da própria força da democracia.

\footnotetext{
28“"A garantia do valor eqüitativo para as liberdades políticas é incluída no primeiro princípio de justiça porque resulta essencial para estabelecer uma legislação justa e também para assegurar que o processo político eqüitativo especificado pela constituição esteja aberto a todos numa base de igualdade aproximada. A idéia é incorporar à estrutura básica da sociedade um procedimento político efetivo que espelhe nessa estrutura a representação eqüitativa de pessoas alcançada na posição original." In: RAWLS, John. O Liberalismo Político. 2 ed. Trad. Dinah de Abreu Azevedo. São Paulo: Ática, 2000, pp. 386-387.
} 


\section{CONSIDERAÇÕES FINAIS}

A liberdade como uma fundamentação filosófica do Estado de Direito sofreu vicissitudes desde o liberalismo clássico até a era contemporânea. Ainda que com a modificação do sentido para este mesmo significante, o contratualismo continua sendo um método para a legitimação das instituições jurídicas. Em uma predominância do pensamento utilitarista, o contratualismo ressurge com Rawls para uma nova concepção de proteção de liberdades contra a regra imposta da maioria.

A história dos direitos fundamentais se coaduna com a construção da ideia de liberdade a partir da Modernidade. Nesse sentido, o contratualismo, como abordagem de legitimação do poder Estatal está intimamente relacionado com a construção da ideia da liberdade dos modernos.

Observar as vicissitudes da ideia de liberdade é compreender o sentido atual que a ideia de liberdade representa no Estado de Direito. Apesar de acepções diferentes, algo é comum entre as vertentes do contratualismo: a compreensão do indivíduo como um ser fora do mundo político construído. O Estado serve a uma finalidade, mas não é a finalidade do homem.

Conforme foi visto, o fim do Estado é a proteção aos direitos fundamentais. Para tal, com o tempo foram criados mecanismos de controle do poder para atender a tal finalidade, como a divisão dos poderes, a transferência da titularidade da soberania do Estado para o povo e o princípio da legalidade. O contratualismo legitima a proteção ao indivíduo, pressupondo uma dicotomia entre Estado e sociedade, constructos da razão humana.

Ao se conceber o indivíduo como imaculado ao ser do Estado, é possível imaginar que o individualismo foi um ponto chave para a compreensão de direitos fundamentais no século XVII e posteriormente. A emergência do Constitucionalismo normativo na modernidade se coaduna com a proteção ao indivíduo contra o Estado, servindo como instrumento de controle do poder político de forma a assegurar as separações necessárias do Estado Liberal.

No século XX, com as preocupações humanitárias no pós-segunda guerra, o individualismo do Estado Liberal é repensado com a emergência e fortalecimento Estado de Bem-Estar, que não somente deve assegurar a vida, mas a vida humana com dignidade. Projeta-se uma sociedade em que o homem possa viver com o direito a exercer seus direitos e liberdades, direito ao seu desenvolvimento pessoal e em relação à sociedade onde vive.

O ser humano idealizado a partir da segunda metade do século XX é um ser humano que não somente solto em um mundo dependente de seus próprios esforços, mas sim em um mundo onde deve haver uma preocupação social com sua dignidade. Isso quer dizer que o ser humano pode se desenvolver plena- 
mente sua consciência, mas para tal, é necessária a preocupação com o seu desenvolvimento pessoal, além de uma concepção do desenvolvimento puramente sob um viés econômico.

Como pressupõe Rawls, a liberdade é uma categoria de prioridade na formulação de uma estrutura básica da sociedade a ser justa porque é o que permite a individualização do homem, ou seja, é o que possibilita em primeiro lugar o homem estar no mundo. Para tal, é imprescindível que em uma sociedade justa, a Constituição será justa se fornecer mecanismos de garantias das liberdades individualizantes, em uma acepção mais ampla que meramente reduzir o homem à sua própria propriedade privada.

O contratualismo, ainda que surgido inicialmente como uma abordagem a se legitimar o poder do Estado, encontra em Rawls um substrato de justiça diversa ao discurso do direito natural. A liberdade não é um direito natural, é um direito humano criado artificialmente para se assegurar as prioridades que os homens entenderiam em uma sociedade justa. É o resultado de uma escolha racional em prol do desenvolvimento pessoal em condições igualitárias dentro do possível.

\section{REFERÊNCIAS}

BALOGUN, M. J. Hegemony and svereign equality: the interest contiguity in International Relations Springer. New York: Springer, 2011.

BARRETTO, V. O fetiche dos direitos humanos e outros temas. 2. ed. Porto Alegre: Livraria do Advogado, 2013.

BILLIER, J-C; MARYIOLI, A. História da filosofia do direito. Tradução Maurício de Andrade. Barueri: Manole, 2005.

CHÂTELET, F. História da filosofia: ideias, doutrinas. Tradução Guido de Almeida. Rio de Janeiro: Zahar, 1974. v. 5.

CHEVALLIER, J-J. As grandes obras políticas de Maquiavel a nossos dias. São Paulo: Agir, 1989.

DOUZINAS, C. O fim dos direitos humanos. Tradução Luzia Araujo. São Leopoldo: Unisinos, 2009.

FARAGO, F. A justiça. Tradução de Maria José Pontieri. Barueri: Manole, 2004. 
FERNANDES, A. de P. A fundamentação ética do direito internacional em Kant: à paz perpétua. Revista Prisma Jurídico, São Paulo, n. 3. p. 149-166, 2004.

FERRAZ JUNIOR, T. S. Introdução ao estudo do direito. 5. ed. São Paulo: Atlas, 2007.

KANT, I. À paz perpétua. Tradução Marco Zingano. Porto Alegre: L\&PM Pocket, 2011.

. Fundamentação da metafísica dos costumes. Tradução Tania Maria Bernkopf São Paulo: Abril Cultural, 1983. (Os Pensadores).

KELSEN, H. O problema da justiça. 5. ed. Tradução João Baptista Machado. São Paulo: M. Fontes, 2011.

LOCKE, J. Segundo tratado sobre o governo. São Paulo: Abril Cultural, 1979. (Os Pensadores).

MAIA, A. C. Sobre a teoria constitucional brasileira e a Carta Cidadã de 1988: do Pós-positivismo ao Neoconstitucionalismo. Revista Quaestio Iuris, Rio de Janeiro, n. 6, v.1, p. 1-85, 2009.

MELO, F. A. de. John Rawls: uma noção de justiça. Lisboa: Faculdade de Direito da Universidade Nova Lisboa Working Papers, 2001. p.1-13.

NOVAIS, J. R. Contributo para uma teoria do estado de direito: do estado de direito liberal ao estado social e democrático. Lisboa: Almedina, 2006.

NOUR, S. À paz perpétua de Kant: filosofia do direito internacional e das relações internacionais. São Paulo: M. Fontes, 2004.

O legado de Kant à filosofia do direito. Revista Prisma Jurídico, São Paulo, n. 3, p. 91-103, 2004.

RAWLS, J. O liberalismo político. Tradução Dinah de Abreu Azevedo. 2. ed. São Paulo: Atica, 2000.

The law of peoples: with the idea of public reason revisited.

Cambridge: Harvard University Press, 1999. 
. Uma teoria da justiça. Tradução Jussara Simões. São Paulo: M. Fontes, 2008.

ROUSSEAU, J-J. Do contrato social. Tradução Lourdes Santos Machado. 2. ed. São Paulo: Abril Cultural, 1979. (Os Pensadores).

SCANLON, T. M. Contractualism and utilitarism. In: DARWALL, Stephen. Contractarianism, contractualism. Oxford: Blackwell Publishers, 2003.

SCHNEEWIND, J. B. Autonomy, obligation, and virtue: a overwiew of Kant,s moral philosophy. In: GUYER, Paul (Org.). The Cambridge companion of Kant. Cambridge: Cambridge University Press, 1992. (Cambridge Companions).

SEN, A. Desenvolvimento como liberdade. Tradução Laura Teixeira Mota. São Paulo: Companhia das Letras, 2010.

STRECK, L. L. Verdade e consenso. 3. ed. Rio de Janeiro: Lumen Juris, 2009.

TELLES JUNIOR, G. O direito quântico. São Paulo: Max Limonad, 1985.

\title{
EQUAL LIBERTY IN THE RULE OF LAW UNDER THE PERSPECTIVE OF JOHN RAWLS'S CONTRACTUALISM
}

\begin{abstract}
This paper intends to show how the principle of equal liberty is present in the contemporary conception of the rule of law. The equal liberty as a conception of justice, developed in the work of Rawls, from a contractualism perspective, has a referential role to reach a fair Constitution. Then, the investigation discusses the role of liberty in the main theories of classic contractualism. After, is shows the Kantian influences on Rawls' thinking, mainly regarding the contractualism approach to obtain a reasonable conception of justice, based on a liberty system in the Rule of Law.

KEYWORDS: Equal liberty; Contractualism; John Rawls.

\section{LA LIBERTAD IGUAL EN EL ESTADO CONSTITUCIONAL DE DERECHO BAJO LA PERSPECTIVA DEL CONTRACTUALISMO DE JOHN RAWLS}

RESUMEN: Este artículo pretende presentar como el principio de libertad igual está presente en la concepción contemporánea de Estado de Derecho. La libertad 
igual como concepción de justicia, desarrollado en el trabajo de Rawls, bajo la perspectiva del contractualismo, tiene un papel referencial para el alcance de una constitución justa. Enseguida, la investigación discute el papel de libertad en las principales teorías del contractualismo clásico. Posteriormente, presentará las influencias kantianas sobre el pensamiento de Rawls, principalmente a respecto del enfoque contractualista para obtener una concepción razonable de justicia, con base en un sistema de libertades en el Estado de Derecho.

PALABRAS CLAVE: Libertad Igual; Contractualismo; John Rawls. 